\title{
Human Values and Professional Ethics
}

\author{
C.Manoharan \\ Professor, AMET Business School, AMET University, Chennai, Tamil Nadu, India
}

\section{OPEN ACCESS}

Volume: 7

Issue: 2

Month: October

Year: 2019

P-ISSN: 2321-4643

E-ISSN: 2581-9402

Received: 20.07.2019

Accepted: 30.09.2019

Published: 03.10.2019

Citation:

Manoharan, C., and B.

Birundha. "Human Values and Professional Ethics."

Shanlax International Journal of Management, vol. 7, no. 2, 2019, pp. 65-69.

DOI:

https://doi.org/10.34293/

management.v7i2.597

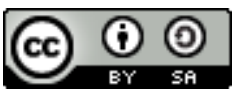

This work is licensed under a Creative Commons Attribution-ShareAlike 4.0 International License.

\section{S.Birundha}

Research Scholar, Bharathiar University, Coimbatore, Tamil Nadu, India

\section{Abstract}

Regardless of what century we live in, despite the fact that the devices we use are changing from forever. Man isn't an animal who can be considered or comprehended without the idea of qualities. Despite the fact that we have various religions, dialects, races and societies, the character of man is constantly developed through qualities. Qualities are factors that straightforwardly impact human life and society in a positive or negative manner. The examination on morals knows the individuals' convictions, qualities, and ethics, become familiar with the great and terrible of them and practice them to boost their prosperity and satisfaction. Likewise, morals reveals to us how to live, to react to issues, through the obligations, rights, duties, and commitments. In religion, comparable standards are incorporated, yet the thinking on methods is constrained. The standards and practices of religions have differed every now and then (history), locale (topography, climatic conditions), religion, society, language, station and statement of faith. Be that as it may, morals has developed to an enormous degree past the boundaries recorded previously. In morals, the center is to think about and apply the standards and practices, generally.

Keywords: Change, Teaching, Morals, Human Dignity, Responsibility, Principles.

\section{Introduction}

The term worth means 'natural worth'. Training is fit for creating solid and standing qualities. Consistently, training has based on worth framework, helpful for the improvement of physical, scholarly, good and otherworldly life. In initiates the dormant limits of the individual empowering the person in question to perceive 'truth', 'obligation' and 'goodness'.

"Proficient morals" is a term that can be comprehended in various ways. In the first place, proficient morals is a code of qualities and standards that guide commonsense choices when they are made by experts. Accordingly, proficient morals might be a pretty much unequivocal and cognizant determinant of activity. It very well may be said that expert morals is a statement and sign of sincere goals that should describe a given calling. Proficient morals can be comprehended from its administration perfect and its related qualities.

\section{Human Values}

Qualities structure the base for every one of our considerations, practices and activities. When we comprehend what is profitable to us, these qualities become the premise, the grapple for our activities. We additionally need to comprehend the all inclusiveness of different human qualities, in light of the fact that at exactly that point we can have a positive and basic program for worth training. At that point no one but we can be guaranteed of a glad and agreeable human culture. 


\section{Morals}

Ethics are the standards articulated by savvy individuals, in view of their experience and intelligence. They were altered, changed or adjusted or advanced to suit the topography of the locale, rulers (administration), and by the improvement of learning in science and innovation.

Profound quality is worried about the standards and practices of ethics, for example,

a) What should or should not to be done in a given circumstance?

b) What is correct or off-base about the treatment of a circumstance? What's more,

c) What is fortunate or unfortunate about the individuals, arrangements, and thoughts included?

\section{Values}

Value is defined as a principle that promotes well-being or prevents harm. "Values are our guidelines for our success - our paradigm about what is acceptable."

\section{Types of Human Values}

There are five core human values as listed here:

(1) Right conduct, (2) Peace (3) Truth (4) Love and (5) Nonviolence.

1. Values related to RIGHT CONDUCT are:

(a) Self Skills: Care of possessions, diet, hygiene, modesty, posture, self reliance and tidy appearance

(b) Social Skills: Good behaviour, good manners, good relationships, helpfulness, No wastage, and good environment, and

(c) Ethical Skills: Code of conduct, courage, dependability, duty, efficiency, initiative, perseverance, punctuality, resourcefulness, respect for all, and responsibility

2. Qualities identified with PEACE are: Attention, serenity, fixation, satisfaction, respect, discipline, fairness, serenity, steadfastness, center, appreciation, joy, agreement, modesty, internal quiet, good faith, tolerance, reflection, fulfillment, self-acknowledgment, fearlessness, poise, self-control, confidence, dignity, sense control, resistance, and understanding
3. Qualities identified with TRUTH are Accuracy, interest, acumen, reasonableness, dauntlessness, genuineness, respectability (solidarity of idea, word, and deed), instinct, equity, confidence, immaculateness, the mission for learning, reason, self-investigation, earnestness, soul of enquiry, union, trust, honesty, and assurance.

4. Qualities identified with LOVE are Acceptance, friendship, care, sympathy, thought, commitment, dedication, compassion, abstinence, pardoning, fellowship, liberality, tenderness, humanness, reliance, benevolence, tolerance, energy, worship, penance, magnanimity, Administration, sharing, compassion, astuteness, resistance and trust.

5. Qualities identified with NON-VIOLENCE are: (a) Psychological: Benevolence, sympathy, worry for other people, thought, self control, absolution, habits, satisfaction, steadfastness, profound quality, and widespread love.

(b) Social: Appreciation of different societies and religions, fraternity, care of the earth, citizenship, fairness, innocuousness, national mindfulness, diligence, regard for property, and social equity.

(c) Perseverance: is characterized as steadiness, assurance, goals, diligence, devotion, duty, consistency, faithfulness, stamina, continuance and relentlessness. To drive forward is portrayed as to proceed, continue, stick at it (casual), continue onward, persevere, plug away, (casual), remain, stand firm, stand quick, hang on and hold tight. Persistence manufactures character.

(d) Accuracy implies opportunity from mix-up or blunder; adjustment to truth or a standard or model and precision. Precision is characterized as accuracy, precision, validness, truth, veracity, closeness to reality (genuine worth) and caution. The estimation of precision grasps a huge region and has numerous ramifications. Designers are urged to show exactness in their conduct through the vehicle of recognition and different motivators. Exactness incorporates coming clean, not misrepresenting, and dealing with one's work.

(e) Discernment implies separation, observation, entrance, and knowledge. Acumen 
implies the ability to perceive what isn't clear to the normal personality. It stresses exactness, particularly in perusing character or intentions. Separation focuses on the ability to recognize or choose what is valid or truly great. Observation suggests brisk and regularly thoughtful insight, as of shades of emotions. Infiltration suggests a looking through mind that goes past what is evident or shallow. Understanding proposes the profundity of insight.

\section{Development of Human Values}

The human qualities develop due to the accompanying elements:

1. The effect of standards of society on the satisfaction of the person's needs or wants.

2. Created or adjusted by one's mindfulness, decision, and judgment in satisfying the necessities.

3. by the educating and routine with regards to Preceptors (Gurus) or Saviors or religious pioneers.

4. Encouraged or changed by social pioneers, leaders of the kingdom, and by law (government)

\section{Ethics}

Ethics is the word that refers to morals, values, and beliefs of the individuals, family or society. The word has several meanings. Basically

- It is an activity and a process of inquiry.

- It is different from non-moral problems when dealing with issues and controversies.

- Ethics refers to a particular set of beliefs, attitudes, and habits of individuals or family or groups concerned with morals.

- It is used to mean 'morally correct' the principles and practices, universally.

\section{Professional Ethics}

The calling is a promise to an assigned and composed occupation by being an expert over an assemblage of information with essential aptitudes gained through specific preparing.

An occupation turns into a calling when a gathering of individuals having a similar occupation work in an ethically worthy manner with individuals setting and following a specific morals code. An expert is a specialist having a place with a particular calling. Proficient morals, instead of individual qualities and profound quality, is a lot of moral norms and qualities a rehearsing architect is required to pursue. It sets the measures for expert practice and is just learned in an expert school or while rehearsing one's calling. Today, it is a basic piece of expert training since it enables understudies to manage issues they will confront.

Proficient morals are those qualities and rules that are acquainted with a person in an expert association. Every representative is intended to carefully pursue these standards. They don't have a decision. Additionally, this methodology is basic in expert settings as it gets a feeling of order individuals just as keeps up decency in workplaces. A few models may incorporate classification, decency, straightforwardness and capability. These morals make the workers mindful.

\section{Features of Professional Ethics}

- Openness

- Transparency

- privacy

- Impartial

- Practical and un-biased

- Loyal

- Co-operative

- Objective oriented

\section{Personal Vs. Professional Ethics}

What is the distinction among individual and expert morals?

The morals that you cling to in your own life and those that you agree inside your expert life are diverse in specific viewpoints. Without specific morals, individuals would be fragmented and shallow. Consequently, they have various frameworks of morals in better places.

The greatest contrast among individual and expert sets of accepted rules is maybe the severity with which individuals fit in with them. The qualities that you characterize for yourself are dependent upon you to be pursued or not to be pursued. Nonetheless, those characterized in an organization or by calling must be trailed by you, since the rupture of these standards or guidelines may hurt your notoriety and 
status. Be that as it may, in the event that you don't hold fast to your morals, it may scarcely have any kind of effect, contingent upon the conditions. And, after its all said and done, you should remember that infringement of your own principles may hurt others around you.

\section{Objectives}

The objectives of Professional Ethics and Human Values are:

(a) To comprehend the virtues that should direct the calling,

(b) Resolve the ethical issues in the calling, and

(c) Justify the ethical judgment concerning the calling.

It is proposed to build up a lot of convictions, demeanors, and propensities that specialists should show concerning profound quality.

The prime goal is to expand one's capacity to manage moral multifaceted nature in administrative practice.

On the other hand, the goals of the investigation on Professional Ethics might be recorded as:

(An) Improvement of the subjective abilities (aptitudes of the astuteness in deduction plainly)

1. Moral mindfulness (capability in perceiving moral issues)

2. Pertinent good thinking (fathoming, surveying various perspectives)

3. Moral cognizance (shaping steady perspectives dependent on actualities)

4. Moral creative mind (looking past evident the elective reactions to issues and being responsive to inventive arrangements)

5. Moral correspondence, to express and bolster one's perspectives to other people.

(B) To act in morally desirable ways, towards moral commitment and responsible conduct

1. Moral sensibility, i.e., willing and ready to be ethically capable.

2. Regard for people, which means demonstrating worry for the prosperity of others, other than oneself.

3. Resilience of assorted variety, i.e., regard for ethnic and religious contrasts, and acknowledgment of sensible contrasts in good points of view.
4. Good trust, for example puts stock in utilizing reasonable exchange for settling good clashes.

5. Trustworthiness, which means moral uprightness, and coordinating one's expert life and individual feelings.

\section{Types of Professional Ethics}

\section{Metaethics: (starting point of moral rule)}

It manages the starting point of moral rules that oversee the particular of good and bad conduct. A noteworthy issue of discussion in this classification is whether moral standards are unceasing realities that advanced from an otherworldly world or basically made by people.

\section{Clear morals: (moral convictions)}

It alludes to the investigation of the ethical convictions of the individuals. It is a field of experimental investigation into what individuals or social orders think about set in stone.

\section{Regulating morals: (self-moral direct)}

It is worried about touching base at a lot of good direct controls against which conduct is judged.

\section{Applied morals}

The moral standards are structured or composed for execution in a particular circumstance as recorded underneath.

a. Bioethics: These are the moral standards or codes for keeping up an ordinary job.

b. Medicinal morals: The moral standards or codes intended for a restorative calling.

c. PC morals: The moral standards or codes intended for a medicinal calling.

d. Building morals: The moral standards or codes intended for a designing calling.

e. Business morals: The moral standards or codes intended for a business activity.

f. Legitimate morals: The moral standards or codes intended for keeping up a lawful framework.

\section{Conclusion}

To meet the social problems and to develop happiness and well-adjusted citizens, certain values are needed within the personality of learners, values or virtues must be integral to the whole process of education. Here, we need powerful reminders, in a variety of ways, of the ahimsa, peace, and harmony'. Human Values and professional ethics with good 
practice and implementation with good efforts will surely be able to produce good citizen with enhanced moral values and character, better personalities along with increased social skills and capabilities, who are happy within themselves and can make others happy, these, in turn, make more socially adjusted and better citizen for the society and country.

\section{References}

Burbules, N and Densmore, K. "The Limits of Making Teaching a Profession." Educational Policy, vol. 5, no. 1, 1991, pp.44-63.

Campbell, E. The Ethical Teacher (Professional Learning). Open University Press, Maidenhead and Philadelphia, 2003.

Chen, W. "How Education Enhances Happiness: Comparison of Mediating Factors in Four East Asian Countries." Social Indicators Research, vol. 106, no. 1, 2012, pp. 117-131.

Darling-Hammond, L. "Constructing 21st-century Teacher Education." Journal of Teacher Education, vol. 57, no. 3, 2006, pp. 300-314.

Delores J. "Learning: The Treasure Within. International Commission on Education report to UNESCO." UNESCO Publishing, France, 1998.
Evans, L. "Professionalism, Professionality and the Development of Education Professionals." British Journal of Educational Studies, vol. 56 , no. 1,2008 , pp. 20-38.

Gerdtham UG and Johannesson M. The Relationship between Happiness, Health and SocioEconomic Factors: Results Based on Swedish Microdata, Working Paper Series, Sweden, 1997.

Oosterbeek JHH. Health, wealth, and happiness: why pursue higher education? Retrieved from http://papers. tinbergen.nl/97034.pdf, 1997.

Parankimalil, J. Value Education, Educationist, 2015.

Sabates, R and Hammond, C. "The Impact of Lifelong Earning on Happiness and WellBeing." International Journal of Lifelong Education, vol. 30, no. 3-3, 2008, pp. 403420.

Salinas Jiménez, et al. "Education as a Positional Good A Life Satisfaction Approach.” Social Indicators Research, vol. 103, no. 3, 2011, pp. 1-19.

\section{Author Details}

C.Manoharan, Professor, AMET Business School, AMET University, Chennai, Tamil Nadu, India.

Email ID: chinniahmanoharan@gmail.com.

S.Birundha, Research Scholar, Bharathiar University, Coimbatore, Tamil Nadu, India. 